\title{
PENDIDIKAN MITIGASI BENCANA GEMPA BUMI DI SDN 1 DAN SDN 2 GANTI PRAYA TIMUR LOMBOK TENGAH
}

\author{
Muhammad Tahir ${ }^{1)}$, Safruddin $^{1}$, Radiusman ${ }^{1)}$, Nursaptini ${ }^{11}$ \\ ${ }^{1)}$ Pendidikan Guru Sekolah Dasar, FKIP, Universitas Mataram, Nusa Tenggara Barat \\ Corresponding author : Radiusman \\ E-mail : mtahir_fkip@unram.ac.id
}

Diterima 07 September 2020, Direvisi 03 Oktober 2020, Disetujui 05 Oktober 2020

\begin{abstract}
ABSTRAK
Pendidikan mitigasi bencana merupakan salah satu kegiatan pengabdian kepada masyarakat yang dilakukan oleh prodi pendidikan guru sekolah dasar Universitas Mataram. Kegiatan ini bertujuan untuk memberikan pengetahuan dan pemahaman tentang kesiapsiagaan bencana gempa bumi dan hal-hal yang harus dilakukan sebelum bencana (prabencana), saat bencana dan setelah bencana terjadi (pascabencana). Kegiatan pengabdian dilakukan di SDN 1 dan SDN 2 Ganti, Lombok Tengah. Kegiatan ini dihadiri oleh kepala sekolah, guru dan pegawai sekolah mitra yang berjumlah 22 orang dan dilaksanakan dengan menggunakan protokol kesehatan. Kegiatan yang dilakukan adalah pemaparan materi pendidikan mitigasi bencana, simulasi mitigasi bencana serta pemaparan materi trauma healing. Kegiatan ini berlangsung dengan baik dan lancar serta tujuan kegiatan ini tercapai. Hal ini diperoleh melalui hasil wawancara dengan guru sekolah mitra. Hasil wawancara menunjukkan bahwa guru-guru sekolah mitra dapat mengerti tentang pentingnya pendidikan mitigasi bencana pada usia dini dan caracara menggunakan trauma healing kepada siswa secara khusus dan masyarakat sekitar secara umum.
\end{abstract}

Kata kunci: kegiatan PKM; mitigasi; gempa bumi.

\begin{abstract}
Disaster mitigation education is one of the community dedication activities carried out by the Universitas Mataram primary school teacher education study program. This activity aims to provide knowledge and understanding of earthquake disaster preparedness and what to do before a disaster (pre-disaster), during a disaster, and after a disaster occurs (post-disaster). Community service activities were carried out at SDN 1 and SDN 2 Ganti, Central Lombok. This activity was attended by school principals, teachers, and partner school employees with totalling 22 people and was implemented using health protocols. The activities carried out were the presentation of disaster mitigation education materials, disaster mitigation simulations, and the presentation of trauma healing materials. This activity went well and smoothly and the objective of this activity was achieved. This was obtained through interviews with partner school teachers. The results of the interviews showed that partner school teachers could understand the importance of disaster mitigation education at an early age and ways to use trauma healing for students in particular and the surrounding community in general.
\end{abstract}

Keywords: PKM activities; mitigation; earthquakes.

\section{PENDAHULUAN}

Indonesia merupakan salah satu negara yang dilalui oleh 3 lempengan pegunungan di dunia. Lempengan pegunungan tersebut adalah lempeng Eurasia, lempeng Indo-Australia, dan lempeng Pasifik. Letak geografis ini menyebabkan Indonesia memiliki banyak gunung merapi yang aktif yang menyebabkan pergerakan lempeng dengan banyak frekuensi dan mengakibatkan bencana alam seperti gempa bumi, gunung mrapi dan tsunami (Parwanto \& Oyama, 2014; Toyfur, Pribadi, Wibowo, \& Sengara, 2018). Selain itu, pergerakan tektonik lempeng bumi ini menyebabkan pembentukan patahan-patahan aktif baik di wilayah daratan maupun di dasar laut. Pergerakan lempeng bumi ini menjadi sumber timbulnya gempa bumi tektonik di Indonesia (Amri et al., 2016). Letak Indonesia berdasarkan lempengan bumi dapat dilihat pada Gambar 1.

Gempa bumi merupakan peristiwa bergetar atau bergoncangnya bumi karena pergerakan/pergeseran lapisan batuan pada kulit bumi secara tiba-tiba akibat rotasi bumi (Wang, Guo, \& Shen, 2017). Pergerakan tibatiba dari lapisan batuan di dalam bumi menghasilkan energi yang dipancarkan ke 
segala arah berupa gelombang gempa bumi atau gelombang seismik. Ketika gelombang ini mencapai permukaan bumi, getarannya dapat merusak segala sesuatu di permukaan bumi seperti bangunan dan infrastruktur lainnya sehingga dapat menimbulkan korban beserta rusak dan hilangnya harta benda (Sunarjo, Gunawan, \& Pribadi, 2012). Gempa bumi merupakan salah satu bencana yang sering melanda Indonesia. Dalam dua dekade terakhir, Indonesia mengalami 642 gempa kuat dengan kekuatan $\mathrm{Mw} \geq 6: 0$, 115 gempa besar dengan kekuatan $\mathrm{Mw} \geq 7$ :0dan 7 gempa besar dengan kekuatan Mw $\geq 8: 0$ (Xu \& Burton, 2014).

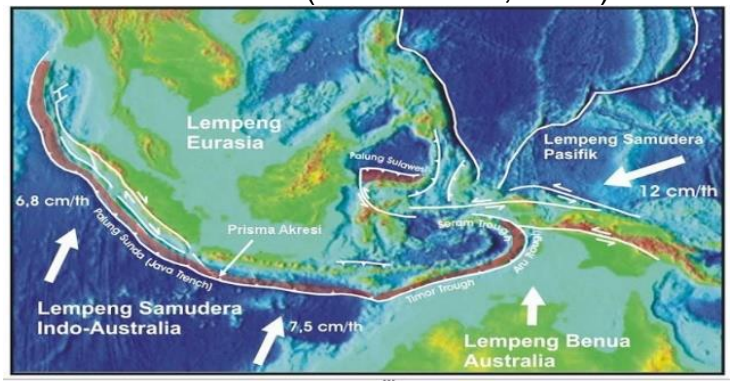

Gambar 1. Letak Indonesia Berdasarkan Lempengan Bumi.

Pulau Lombok merupakan salah satu daerah yang sering dilanda bencana gempa bumi. Secara tektonik Lombok memang kawasan seismik aktif. Pulau Lombok dikelilingi oleh beberapa sumber gempa, yaitu diantaranya zona Back Arc Thrust di wilayah utara, megathrust di selatan, dan sistem sesar geser di sisi barat dan timurnya (Tim Pusat Studi Gempa Nasional, 2018). Banyaknya daerah rawan bencana gempa bumi di Lombok menyebabkan pentingnya peningkatan upaya pengurangan risiko bencana agar korban jiwa serta kerugian materi akibat gempa dapat dikurangi. Perlu adanya persiapan berupa tindakan preventif dan antisipatif dalam mengelola bencana gempa bumi. Salah satu yang dapat dilakukan adalah memperkenalkan mitigasi bencana pada anak usia sekolah. Pendidikan mitigasi bencana di usia dini merupakan salah satu upaya yang diharapkan mampu memberi pengetahuan yang bermanfaat tentang kesiapsiagaan gempa di masa depan

Pendidikan mitigasi bencana gempa bumi sangat penting didapatkan oleh guru maupun siswa. Anak-anak adalah kelompok yang paling rentan selama bencana dan setelah bencana, termasuk gangguan fisik, psikologis dan pendidikan (Peek, 2008). Sekolah sebagai tempat menimba ilmu para generasi muda serta merupakan tempat tinggal kedua para siswa setelah rumah. Sekolah dapat dijadikan tempat dalam memahami dan mempelajari potensi bencana yang sering terjadi di Indonesia, khususnya bencana alam yang sering terjadi di sekitar lingkungan tempat tinggal guru dan siswa. Pendidikan kebencanaan di sekolah dasar dapat membantu peserta didik dalam memberikan peranan penting dalam penyelamatan hidup dan perlindungan anggota masyarakat pada saat terjadi bencana (Proulx \& Aboud, 2019).

Pendidikan mitigasi bencana merupakan sarana yang efektif untuk membangun perilaku guru dan siswa dalam menghadapi bencana. Pengetahuan mitigasi bencana yang dimiliki guru dan siswa dapat mempengaruhi sikap dan kepedulian untuk siap dan siaga dalam mengantisipasi bencana (Masitoh, 2018). Kemampuan guru dan siswa dalam memahami potensi bencana yang terdapat di sekitar tempat tinggalnya (local area) sangat penting, pengetahuan dan keterampilan tersebut menjadi informasi yang sangat membantu apabila terjadi sebuah bencana sebagai antisipasi dini melalui sikap dan nilai-nilai yang mendorong peserta didik untuk bertindak pro sosial, bertanggung jawab dan responsif ketika keluarga dan komunitasnya terancam (Kagawa \& Selby, 2012). Penanggulangan bencana akan berhasil dengan baik jika semua menyadari risiko bencana yang ada serta memiliki kemampuan untuk mengantisipasi bencana atau yang lebih dikenal dengan kesiapsiagaan terhadap bencana. Kesiapsiagaan bencana berhubungan dengan pengetahuan yang cukup kepada masyarakat mengenai bencana yang sering terjadi serta pencegahan dan ketahanan terhadap bencana. Kesiapsiagaan bencana gempa bumi akan dapat dilaksanakan dengan baik jika guru dan siswa memiliki pengetahuan terhadap prabencana, bencana dan pasca bencana.

Berdasarkan hasil analisis yang dilakukan oleh tim pengabdian di sekolah mitra ditemukan bahwa pemahaman siswa tentang mitigasi bencana masih kurang terutama gempa bumi. Pendidikan tentang mitigasi bencana gempa bumi merupakan suatu hal yang penting bagi siswa dan guru. Hal ini disebabkan karena bencana gempa bumi bisa terjadi di mana saja dan kapan saja. Bencana tidak dapat dihindari tapi dapat dikurangi dampak negatifnya atau risiko bencananya. Pengurangan risiko bencana perlu dilakukan dengan cara mengelola risiko bencana. Ada beberapa faktor yang dapat menimbulkan besarnya kerugian dalam bencana antara lain kurangnya pemahaman tentang karakteristik bencana (hazard), sikap dan perilaku yang mengakibatkan rentannya kualitas sumber daya alam (vulnerability), kurangnya informasi 
peringatan dini (early warning) sehingga mengakibatkan ketidaksiapan, ketidakberdayaan atau ketidakmampuan dalam menghadapi bahaya (Amri et al., 2016).

Berdasarkan hasil observasi lapangan diperoleh beberapa masalah di SDN 1 dan SDN 2 Ganti Praya Timur Lombok Tengah yaitu pendidikan mitigasi bencana belum pernah didapatkan secara langsung di sekolah, sekolah belum maksimal berperan dalam membangun kesadaran bencana gempa bumi, serta sekolah belum secara efektif menginternalisasikan pengetahuan mitigasi bencana dalam proses pembelajaran. Melalui permasalahan ini, tim pengabdian kepada masyarakat Universitas Mataram perlu melakukan kegiatan pendidikan mitigasi bencana di SDN 1 dan SDN 2 Ganti, Praya Timur. Kegiatan pengabdian kepada masyarakat ini seharusnya dilakukan kepada guru dan siswa di SDN 1 dan SDN 2 Ganti, namun akibat pandemic covid-19, maka kegiatan ini hanya dilakukan kepada guru-guru SDN 1 dan SDN 2 Ganti.

Kegiatan pengabdian kepada
masyarakat di SDN 1 dan SDN 2 Ganti ini bertujuan untuk meningkatkan pemahaman guru beserta stakeholder lainnya tentang gempa bumi beserta dampaknya, upaya penyelamatan pada saat dan sesudah gempa bumi terjadi, serta tindakan yang harus dilakukan untuk memulihkan mental korban bencana gempa bumi (trauma healing)

\section{METODE}

Kegiatan pengabdian kepada masyarakat ini dilakukan pada waktu masa pandemic covid-19. Kegiatan ini dihadiri oleh kepala sekolah SDN 1 dan SDN 2 Ganti beserta guru-guru dan staf pegawai yang berjumlah 22 orang. Kegiatan pengabdian kepada masyarakat ini menggungkan $\mathrm{m}$ survei lokasi, wawancara, menganilisis permasalahan mitra serta meminta izin kepada kepala sekolah mitra untuk melaksanakan kegiatan pengabdian. Berdasarkan hasil wawancara diperoleh informasi bahwa masih rendahnya pengetahuan guru dan siswa terhadap pengetahuan mitigasi bencana dan kurangnya fasilitas jalur evakuasi yang ada di sekolah mitra. Maka berdasarkan masalah yang ditemukan pada sekolah mitra, maka tim pengabdi perlu melakukan kegiatan pendidikan mitigasi bencana sebagai solusi permasalahan di desa mitra.

Kegiatan yang akan dilakukan pada kegiatan pengabdian kepada masyarakat adalah memberikan pendidikan terhadap guru mengenai kesadaran dan kesiapsiagaan bencana gempa bumi, melakukan simulasi mitigasi bencana gempa bumi dan memaparkan kegiatan yang harus dilakukan setelah bencana gempa bumi terjadi serta cara menyembuhkan korban yang mengalami bencana secara psikologis dan mental (trauma healing).

\section{HASIL DAN PEMBAHASAN}

Kegiatan pengabdian masyarakat ini tetap dilakukan dengan protocol kesehatan yaitu memakai masker dan jaga jarak. Kegiatan pembuka diawali dengan sambutan dari kepala sekolah SDN 2 Ganti dan dilanjutkan oleh ketua tim pengabdi. Kegiatan pemamparan materi pendidikan mitigasi bencana di SDN 1 dan SDN 2 Ganti dilakukan dalam tiga sesi dengan subtema yang berbeda-beda. Tema-tema yang dibawakan oleh narasumber adalah pentingnya pendidikan mitigasi bencana gempa bumi, simulasi mitigasi bencana gempa bumi dan pemaparan cara-cara menyembukan korban yang mengalami bencana secara psikologis dan mental (trauma healing).

Pada tema ini, narasumber memaparkan materi mengenai letak geografis Indonesia ditinjau dari posisi lempengan bumi yang ada di Indonesia, letak geografis Lombok berdasarkan sumber-sumber gempa seperti zona back art thrust di wilayah utara Lombok, megathrust di wilayah selatan Lombok serta sistem sesar geser yang berada di sebalh barat dan timur Lombok, prinsip bencana, definisi dari mitigasi bencana. Pada saat sub tema pertama berlangsung, narasumber juga menunjukkan video tentang terbentuknya kepulauan Indonesia secara umum dan pulau Lombok secara khusus. Adapun dokumentasi pemaparan narasumber pertama dan antusias peserta dapat dilihat pada Gambar 2.

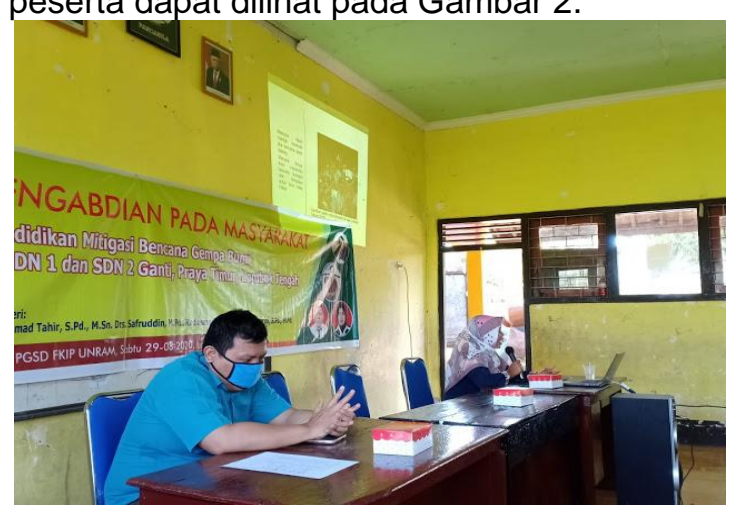

Gambar 2. Pemaparan Materi Narasumber Pertama.

Kegiatan selanjutnya adalah pemaparan materi simulasi mitigasi bencana. Kegiatan awal dimulai dengan pemaparan materi sikap yang harus dilakukan dalam prabencana, saat bencana terjadi dan setelah bencana terjadi. Berdasarkan pemaparan, terdapat beberapa kegiatan yang harus 
dilakukan pada kegiatan prabencana, antara lain: mengikuti ketentuan dalam membangun rumah (RTG), meletakkan perabotan rumah di tempat yang aman, menyiapkan alat komunikasi dan kotak P3K ditempat yang mudah dijangkau, memiliki jalur evakuasi serta mencatat nomor-nomor penting seperti aparat desa, rumah sakit dan aparat kepolisian. Selanjutnya, narasumber memaparkan kegiatan yang harus dilakukan pada saat terjadi bencana. Adapun kegiatan yang harus dilakukan ketika dalam keadaan gempa bumi adalah tidak panik, berlindung di bawah meja, menjauhi benda-benda yang kemungkinan akan jatuh saat terjadi gempa, menjauhi tiang listik maupun pohon yang berpotensi tumbang saat gempa, menjauhi pantai dan tidak menggunakan lift saat gempa berlangsung.

Narasumber kemudian memaparkan hal-hal yang harus dilakukan pasca gempa. Adapun kegiatan-kegiatan yang dilakukan pasca gempa adalah mengikuti jalur evakuasi untuk menyelamatkan diri, keluar menuju pintu keluar dengan tertib, mewaspadai bencana susulan, serta menghubungi aparat desa, rumah sakit dan aparat keamanan. Kegiatan berikutnya adalah melakukan gerakan simulasi gempa. Gerakan ini diambil dari video yang diunggah oleh kementerian pemberdayaan perempuan dan perlindungan anak. Video ini berisi gerakan-gerakan yang harus dilakukan ketika bencana dan pasca bencana. Sebelum melakukan kegiatan simulasi mitigasi bencana, maka tim pengabdi melakukan gerakan pemanasan. Selanjutnya, dengan panduan tim pengabdi, semua peserta melakukan gerakan mitigasi bencana. Adapun pemaparan narasumber dan gerakan simulasi gempa dapat dilihat pada Gambar 3.

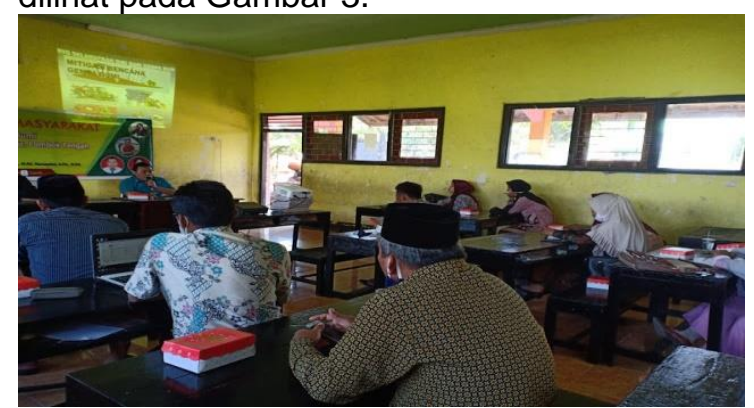

Gambar 3. Narasumber Memaparkan Materi Simulasi Gempa Bumi.

Kegiatan selanjutnya adalah narasumber memaparkan cara mengobati dan memulihkan psikologis dan mental korban gempa (trauma healing). Pada kegiatan ini, narasumber memaparkan materi mengenai defenisi trauma, penyebab terjadi trauma pada seseorang, defenisi trauma healing, serta kegiatan-kegiatan yang harus dilakukan pada saat kegiatan trauma healing. Adapun kegiatan yang dapat dilakukan pada saat pelaksaan trauma healing antara lain: meminimalisir korban dalam melihat atau mendengarkan media mengenai bencana yang sedang terjadi, menempatkan korban di tempat yang aman, melakukan kegiatan yang menarik kepada korban seperti bercanda, menggambar, menyanyi dan melakukan permainan, mau mendengarkan cerita dari korban dan menunjukkan sikap empati dan simpati, serta memberikan donasi kepada korban bencana.

Narasumber juga memaparkan bahwa kegiatan trauma healing merupakan kegiatan yang instan dalam upaya menyembuhkan trauma pada korbang. Kegiatan trauma healing harus dilakukan secara konsinsten serta menyentuh pikiran dan fisik korban. Hal ini bertujuan agar korban dapat kembali dalam keadaan normal. Adapun kegiatan pemaparan materi oleh narasumber mengenai kegiatan trauma healing dapat dilihat pada Gambar 4.

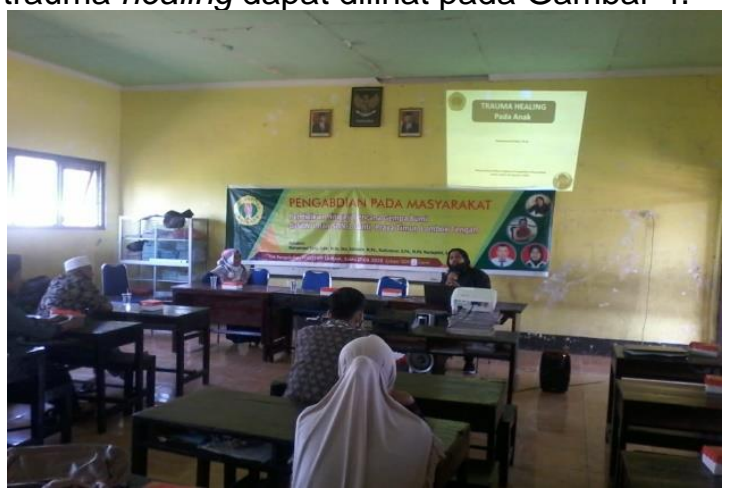

Gambar 4. Pemaparan Materi Trauma Healing.

Kegiatan berikutnya yang dilakukan kegiatan pengabdian mitigasi bencana ini adalah kegiatan tanya jawab dengan peserta kegiatan mengenai hal-hal berkaitan dengan mitigasi bencana. Beberapa pertanyaan yang diberikan peserta kepada narasumber antara lain mengenai trauma healing dan mengapa kegiatan mitigasi tetap dilakukan pasca bencana terjadi. Adapun sesi tanya jawab dapat dilihat pada Gambar 5.

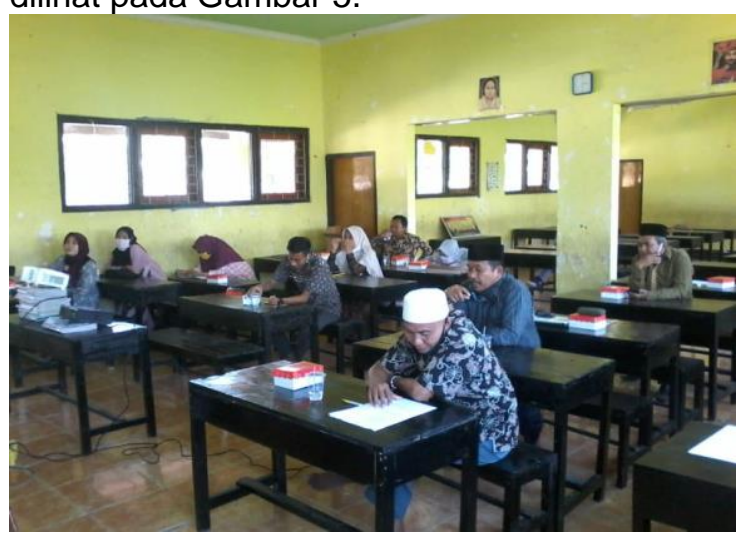


Gambar 5. Kegiatan Tanya Jawab dengan Peserta.

Kegiatan berikutnya adalah narasumber menjawab beberapa pertanyaan yang telah diberikan oleh peserta. Setelah narasumber menjawab pertanyaan kepada narasumber maka narasumber meminta kepada peserta kegiatan pengabdian agar mengimplemetasikan pendidikan mitigasi bencana ini kepada siswa pada saat kegiatan belajar mengajar sudah dpat dilakukan secara tatp muka. Kegiatan selanjutnya adalah melakukan kegiatan penutup berupa kesan dan pesan dari peserta kegiatan pengabdian kepada masyarakat. Selanjutnya tim pengabdi melakukan wawancara dengan beberapa guru mengenai manfaat kegiatan pengabdian tentang pendidikan mitigasi bencana.

\section{SIMPULAN DAN SARAN}

Berdasarkan kegiatan pengabdian yang dilakukan di SDN 1 dan SDN 2 Ganti dapat diambil beberapa kesimpulan yaitu guru dapat mengetahui pentingnya kesiapsiagaan dalam menghadapi bencana, guru dapat mengetahui hal-hal yang harus dilakukan pada saat bencana dan pasca bencana terjadi, guru dapat mengetahui pentingnya tanda jalur evakuasi di sekolah, serta guru dapat memahami pentingnya trauma healing kepada siswa. Selanjutnya melalui kegiatan pengabdian kepada masyarakat ini guru diharapkan mampu melakukan kegiatan simulasi bencana kepada anak-anak ketika pandemic covid-19 telah selesai. Pihak sekolah juga mengharapkan kegiatan pengabdian kepada masyarakat sering dilakukan di sekolah mitra sehingga dapat lebih meningkatkan pengetahuan dan menambah pengalaman yang baru kepada guru-guru di sekolah mitra.

\section{UCAPAN TERIMAKASIH}

Kegiatan ini dapat dilaksanakan atas dukungan dari LPPM Universitas Mataram dan dibiayai dengan dana PNBP Universitas Mataram.

\section{DAFTAR RUJUKAN}

Amri, M. R., Yulianti, G., Yunus, R., Wiguna, S., Adi, A. W., Ichawana, A. N., ... Septian, R. T. (2016). Risiko bencana indonesia (R. Jati \& M. R. Amri, Eds.). Jakarta: Badan Nasional Penanggulangan Bencana.

Kagawa, F., \& Selby, D. (2012). Ready for the Storm: Education for Disaster Risk Reduction and Climate Change Adaptation and Mitigation. Journal of Education for Sustainable Development,
6(2), 207-217. https://doi.org/10.1177/09734082124752 00

Masitoh, Y. (2018). Pengurangan Risiko Bencana Gempabumi pada Komunitas Sekolah Dasar di Kecamatan Lembang Kabupaten Bandung Barat (Vol. 9).

Parwanto, N. B., \& Oyama, T. (2014). A statistical analysis and comparison of historical earthquake and tsunami disasters in Japan and Indonesia. International Journal of Disaster Risk Reduction, 7, 122-141. https://doi.org/10.1016/j.ijdrr.2013.10.00 3

Peek, L. (2008). Children and Disasters: Understanding velnurability, developing capacities, and promoting resilience-an introduction. Children Youth Environ, 18(1), 1-29.

Proulx, K., \& Aboud, F. (2019). Disaster risk reduction in early childhood education: Effects on preschool quality and child outcomes. International Journal of Educational Development, 66(January), $1-7$.

https://doi.org/10.1016/j.ijedudev.2019.0 1.007

Sunarjo, S., Gunawan, M. T., \& Pribadi, S. (2012). Gempabumi Edisi Populer. Jakarta: Badan Meteorologi Klimatologi dan Geofisika.

Tim Pusat Studi Gempa Nasional. (2018). Kajian Rangkaian Gempa Lombok Provinsi Nusa Tenggara Barat (M. Irsyam, N. R. H. Hanifa, \& D. Djarwadi, Eds.). Bandung: Kementerian Pekerjaan Umum dan Perumahan Rakyat.

Toyfur, M. F., Pribadi, K. S., Wibowo, S. S., \& Sengara, I. W. (2018). Vulnerability factor in earthquake risk assessment model for roads in Indonesia. MATEC Web of Conferences, 229. https://doi.org/10.1051/matecconf/20182 2903009

Wang, B., Guo, J., \& Shen, B. (2017). Cell Based Evolutionary Virtual World Framework. Proceedings - 14th IEEE International Conference on E-Business Engineering, ICEBE 2017 - Including 13th Workshop on Service-Oriented Applications, Integration and Collaboration, SOAIC 207, 255-262. https://doi.org/10.1109/ICEBE.2017.48

Xu, Y., \& Burton, P. W. (2014). Survival of seismogenesis: Cox proportional hazard model of large earthquakes in indonesia. Seismological Research Letters, 85(4), 794-800. https://doi.org/10.1785/022013054 